\title{
Relationship aggressiveness of prostate cancer with tumor-associated serum markers
}

\author{
Yu.V. Lozovska ${ }^{1}$, L.A. Naleskina ${ }^{1}$, T.V. Zadvorniy ${ }^{1}$, I.M. Andrusishina ${ }^{2}$, I.V. Zhulkevych ${ }^{3}$, \\ E.O. Stakhovskiy ${ }^{4}$, L.M. Kunska ${ }^{1}$, N.Yu. Lukianova ${ }^{1}$ \\ ${ }^{1}$ RE. Kavetsky Institute of Experimental Pathology, Oncology and Radiobiology, NAS of Ukraine, \\ Kyiv; \\ ${ }^{2}$ SI "Yu.I. Kundiev Institute of Occupational Health", NAMS of Ukraine, Kyiv; \\ 3 Ivan Horbachevsky Ternopil National Medical University; \\ ${ }^{4}$ National Cancer Institute, Kyiv; e-mail:Lozovskaya.2012@ukr.net
}

\begin{abstract}
The content of lactoferrin (LF), C-reactive protein (CRP), albumin, lactate dehydrogenase (LDH), as well as $\mathrm{Ca} / \mathrm{Mg}$ and $\mathrm{CRP} /$ albumin ratios in sera of patients with prostate cancer were analyzed in relation to the clinical and pathological features of the disease including the malignancy degree (Gleason score) and the presence of metastases to regional lymph nodes. In the serum of patients with stage III, LF content was lower (1.4 times) and CRP/albumin ratio $<0.5$ than in patients with stage II, while CRP content and Ca/Mg ratio increased (2.75 and 1.12 times, respectively). In addition, in patients with metastatic lesions of regional lymph nodes, a decrease in LF content (1.3-fold) and level of albumin (1.16-fold) and a simultaneous increase in CRP, Ca/Mg (2.84 and 1.1 times, respectively) and CRP/albumin ratios lower $(<0.5)$ were evident. In serum of patients with tumors of high malignancy degree ( 8 and 9 points by Gleason score) and prostatespecific antigen (PSA) level exceeding $4 \mathrm{ng} / \mathrm{ml}$, LF content and CRP/albumin ratio decreased whereas CRP content and $\mathrm{Ca} / \mathrm{Mg}$ ratio were increased, LDH activity in serum of these patients also increased significantly. Therefore, some differences in metabolic pathways in patients with prostate cancer of highly aggressive course have been elucidated. Comparative study of the content of extratumoral serum PC markers (LF, $P S A$, albumin, $\mathrm{LDH}, \mathrm{Ca} / \mathrm{Mg}$, CRP/albumin), depending on the clinical manifestations of the tumor process showed that serum LF can be used as an extratumoral marker, which provides new additional information on the features of the clinical course of the disease.

Key words: prostate cancer, tumor-associated biochemical markers, prostate-specific antigen, Gleason score.
\end{abstract}

\section{INTRODUCTION}

During the last decade, there is observed a clear trend towards an increase in the incidence of prostate cancer (PC) among the population in most countries, including Ukraine [1,2]. According to the latest data from the American Cancer Society (ACS), this pathology is ranked second among the causes of death from malignant neoplasms in men of different age categories [3]. The percentage of PC patients younger than 60 years increases as well $[4,5]$.

Despite the existence of modern informational biochemical markers for the identification of initial PC stages with high metastatic potential, the clinical practice still continues to focus on the determination of the serum level of prostatespecific antigen (PSA), which, unfortunately, does not allow predicting the course of the tumor process [6]. The "golden standard" for determining the degree of malignancy of the prostate tumors remains their histological evaluation by the Gleason scale, which is based on the morphological picture of the two tumor regions with the most characteristic degree of anaplasia. It is believed that if the total Gleason scores higher than 7, then this indicate an unfavorable course of $\mathrm{PC}$, which requires intensive treatment tactics [7].

It is known that the serum PSA values and the morphological score by the Gleason scale allow assessing the characteristics of the processes

(C) Yu.V. Lozovska, L.A. Naleskina, T.V. Zadvorniy, I.M. Andrusishina, I.V. Zhulkevych, E.O. Stakhovskiy, L.M. Kunska, N.Yu. Lukianova 
occurring in the primary lesion, without taking into account the variety of metabolic alterations occurring at the level of the organism.

At present, the clinical significance of the serum marker - C-reactive protein (CPR) as a marker for the generalization of the process in PC patients has been proved; it serves as a highly informative index of acute and chronic inflammation and is simultaneously involved in the mechanisms of insulin resistance, cytokine disorders, and also in the development of endothelial dysfunction [8,9]. Along with this, it was found that it is expedient to determine not only the content of PSA but also albumin and their ratio in blood serum (BS) of the PC patients, since these biochemical parameters reflect the changes in the metabolism in the whole body, in particular, the functioning of transport protein of blood and the processes of inflammation associated with lymphogenous and hematogenous metastases and decreased life expectancy of patients $[10,11]$. Other researchers have shown the activation of the process of aerobic glycolysis in the development and progression of aggressive forms of $\mathrm{PC}$, which in turn affects the content of lactate dehydrogenase (LDH) [12]. Some researchers consider it equally important for diagnostic purposes to use $\mathrm{Ca} / \mathrm{Mg}$ ratios in the BS of PC patients, especially for the detection of highly malignant forms, since these elements take part in the activation of the calciumdependent pathway of the epithelial-mesenchymal transition through the transient receptor potentialmelastatin-like (TRPM7), which is characteristic of this pathology [13]. However, the informativeness of some of the biochemical markers concerning the course of PC remains insufficiently highlighted and requires a more in-depth study [10-13].

A significant omission is the fact that there are no comprehensive data on the clinical significance of lactoferrin (LF) - a protein with unique biological properties that participates in iron metabolism, immune response modeling, growth factor regulation in relation to patients with PC $[14,15]$.

It should be noted that the above biochemical parameters were not investigated simultaneously in each individual PC patient in relation to the clinical and pathological characteristics of the disease and the diagnostic and prognostic significance of each of them among the total number of investigated markers was not determined. Therefore it seems reasonable to assess the level of informativeness of each serum extratumoral marker, including LF, concerning the most commonly used clinical indices of the course of the tumor process in patients with PC.

The aim of our work was to determine the informative and prognostic significance of extratumoral serum markers: the content of LF, PSA, albumin, $\mathrm{LDH}$, also $\mathrm{Ca} / \mathrm{Mg}$ and $\mathrm{CRP} /$ albumin ratios, depending on the clinical and pathological characteristics of the tumor process in PC patients.

\section{METHODS}

The study involved 120 patients with PC of stages II-III diagnosed on the base of clinical examination, in particular: determination of PSA level, palpal rectal examination, computed tomography (CT) of pelvic organs and/or transrectal ultrasound of the prostate gland with tissue biopsy, osteoscintigraphy, radiography of the chest, ultrasound of the abdominal cavity. The stage of the tumor process in all PC patients is determined according to the International Classification (TNM, 2002, sixth edition).

In all patients, along with the histological diagnosis and assessment of malignancy degree by Gleason score, also age, tumor size and the presence of metastases in regional lymph nodes were taken into account. The lymph node metastasis is detected in 70 patients with PC. All patients were treated at the Department of Oncourology of the National Cancer Institute during 2015-2017. The patients were not prescribed to radiation and neoadjuvant polychemotherapy. All the patients provided an informed voluntary consent of the use of their materials for scientific purposes. The control group consisted of 20 conditionally healthy men, without clinical symptoms and manifestations of PC.

Morphological studies, including the verifi- 
cation of the histological diagnosis, according to the International Histological Classification of the WHO (2002), and the determination of the degree of tumor malignancy by Gleason, were performed on the samples of surgically resected tumors treated by standard techniques; the slides were stained with hematoxylin and eosin.

The content of serum LF was determined using a solid-phase ELISA assay using the test systems Max Human Lactoferrin Elisa Assay (USA). The determination of the serum PSA, albumin and LDH content in BS of the patients was carried out using biochemical methods and liquid stable reagents on the Chem Well 2990 auto-biochemical and enzyme-linked analyzer. Along with this, for each patient the SRP/albumin ratio was calculated. The PSA level was determined on the same device using a set of reagents from the Prostate Specific Antigen ELISA KitDLDevelop (China). The content of $\mathrm{Ca}$ and $\mathrm{Mg}$ in BS of the patients was determined using the method of inductively coupled plasma atomic emission spectroscopy with (ICP-AES) on the Optima 2100 DV ("Perkin-Elmer", USA) [16]. According to the procedure, $4.5 \mathrm{ml}$ of $10 \%$ $\mathrm{HNO}_{3}$ ("Merck") solution was added to $0.5 \mathrm{ml}$ of the BS and centrifuged for $20 \mathrm{~min}$ at 5,000 rpm.

Statistical data was processed using STATISTICA 6.0 software and the MS Excel 2010 application package. The significance of the differences between the groups was evaluated using Student's t-criterion. Differences were considered to be significant at $\mathrm{P}<0.05$. The Pearson correlation coefficient was calculated.

\section{RESULTS AND DISCUSSION}

General characteristics of patients with prostate cancer. All 120 patients with PC were analyzed according to the main clinical and morphological characteristics. The average age of patients was $62.2 \pm 9.011$ years ranging from 45 to 85 years. By stage of the tumor process (according to the TNM classification, category T), they were distributed as follows: II stage $-41.9 \%$, III stage $-58.1 \%$. Metastatic involvement of regional lymph nodes (category $\mathrm{N}$ ) was detected in 70 patients $(58.3 \%)$, in 50 patients $(41.6 \%)$ no metastases were identified. The malignancy degree of PC by the Gleason score was 7 points in $56.6 \%$ patients, 6 points in $25 \%$ patients, 8 points in $13.3 \%$ patients, and 9 points in $5 \%$ patients.

In the vast majority of PC patients $(86.6 \%)$ serum PSA levels exceeded $4 \mathrm{ng} / \mathrm{ml}$, only a small percentage of patients $(13.3 \%)$ this index was lower than $4 \mathrm{ng} / \mathrm{ml}$, which allowed distribution of all subjects to two conditional subgroups

In the morphological study of the surgical material of PC patients, small and large-acinar types of adenocarcinoma (55 and 40 tumors, respectively) and their combination (25 tumors) were determined.

The analysis of the investigated serum parameters was carried out according to the above-mentioned clinical characteristics of patients with PC and morphological features of tumors. Since the main task of the study was to determine the content of LF in the blood serum of patients with PC, depending on the clinical and pathological characteristics, the comparison of the content of this protein in conditionally healthy men and PC patients was carried out.

The results showed that LF levels in patients with $\mathrm{PC}$ are 6 times lower $(\mathrm{P}<0.05)$ for those in the group of conditionally healthy men. This became the reason for further studies of this index in terms of the possibility of using it as an extratumoral marker for diagnosing neoplasms of the prostate gland. The appropriateness of this direction in relation to the most common hormone-dependent malignant neoplasms is confirmed by the results of our previous studies, obtained on the clinical material of patients with breast cancer [15].

In order to evaluate the significance of LF as a marker of inflammation in patients with $\mathrm{PC}$, along with the study of this protein, we used other biochemical parameters that are already used in clinical practice to diagnose and monitor the course of the tumor process.

At present, the most objective characteris- 
tics that reflect changes in various metabolic disturbances in the body of cancer patients are the following: albumin content - a marker of a violation of the functioning of the transport system of blood proteins, C-reactive protein, and the SRP/albumin ratio - inflammation indices, $\mathrm{Ca} / \mathrm{Mg}$ ratio - one of the characteristics of the epithelial-mesenchymal transition, LDH - an indicator of the intensity of glycolysis. However, the informativeness of some of the biochemical markers on the course of the PC process remains insufficiently highlighted and requires a more in-depth study [10-13].

To determine the degree of informativeness of LF as an extratumoral marker, the content of this protein was compared with the above biochemical indices, as well as with the PSA level, taking into account the clinical and pathological characteristics of patients with PC. The results of the studies showed that there was no significant difference between the content of LF, LDH, PSA, albumin, and LDH in the blood serum of patients with $\mathrm{PC}$, depending on the age of patients. However, an individual analysis showed that in the elderly patients (over 60 years) with a high PSA level (above $4 \mathrm{ng} / \mathrm{ml}$ ), there was a decrease in the ratios of CRP/albumin and $\mathrm{Ca} / \mathrm{Mg}$ compared with those of younger patients (Table 1). The results obtained are in agreement with the literature data $[10,13]$ on the peculiarities of changes in the parameters of $\mathrm{CRP} /$ albumin and $\mathrm{Ca} / \mathrm{Mg}$, depending on the age of patients, and evidence that the disturbance of the transport function of albumin and the activation of the calcium-dependent pathway of the epithelial-mesenchymal transition through the TRPM7 channel is most often detected in younger patients with aggressive PC forms [13].

A somewhat different nature of the changes in these indices was observed in blood serum of patients with PC, depending on the stage of the disease by categories $\mathrm{T}$ and $\mathrm{N}$. It was found that in BS of patients with PC of stage III in comparison with stage II there was a decrease of the content of LF (1.4 times) and the CRP/ albumin ratio $(<0.5)$ on the background of a significant increase in CRP level, and $\mathrm{Ca} / \mathrm{Mg}$ ratio (2.75 and 1.12 times, respectively). It is also shown that these features in individuals of this category are accompanied by high levels of PSA, which proves their informativeness with increasing the size of the tumor lesion.

Table 1. Content of LF, PSA, CRP, albumin, $\mathrm{LDH}$, and ratios of CRP/albumin and Ca/Mg in blood serum of patients with PC, depending on clinical and morphological characteristics of patients $(\mathrm{M} \pm \mathrm{SEM})$

\begin{tabular}{|c|c|c|c|c|c|c|c|}
\hline Index & $\begin{array}{c}\mathrm{LF}, \\
\mathrm{ng} / \mathrm{ml}\end{array}$ & $\begin{array}{l}\text { PSA, } \\
\mathrm{ng} / \mathrm{ml}\end{array}$ & $\begin{array}{l}\mathrm{CRP}, \\
\mathrm{mg} / 1\end{array}$ & $\begin{array}{c}\text { Albumin, } \\
\mathrm{g} / 1\end{array}$ & $\begin{array}{c}\text { CRP/ } \\
\text { albumin } \\
\end{array}$ & $\begin{array}{c}\mathrm{LDH}, \\
\mathrm{U} / 1\end{array}$ & $\mathrm{Ca} / \mathrm{Mg}$ \\
\hline \multicolumn{8}{|c|}{ Age } \\
\hline$<60$ & $180.5 \pm 21.5$ & $<4$ & $3.80 \pm 3.23$ & $42.58 \pm 3.16$ & $>0.5$ & $258.47 \pm 52.43$ & $6.01 \pm 0.12$ \\
\hline$>60$ & $139.8 \pm 19.7$ & $>4$ & $7.15 \pm 1.14$ & $40.62 \pm 4.16$ & $<0.5$ & $275.12 \pm 63.31$ & $5.42 \pm 0.18 *$ \\
\hline \multicolumn{8}{|c|}{ PC stage by TNM (category T) } \\
\hline II & $186.3 \pm 15.3$ & $<4$ & $4.12 \pm 2.16$ & $41.72 \pm 4.92$ & $>0.5$ & $262.63 \pm 86.59$ & $5.78 \pm 0.12$ \\
\hline III & $134.3 \pm 10.1^{*}$ & $>4$ & $11.37 \pm 4.12 *$ & $\begin{array}{l}40.01 \pm 5.06 \\
\text { category } \mathrm{N})\end{array}$ & $<0.5$ & $264.01 \pm 94.32$ & $6.48 \pm 0.24 *$ \\
\hline N"-" & $173.8 \pm 9.5$ & $<4$ & $6.46 \pm 5.12$ & $41.13 \pm 1.12$ & $>0.5$ & $252.21 \pm 61.12$ & $5.56 \pm 0.09$ \\
\hline N"+" & $133.1 \pm 4.3^{*}$ & $>4$ & $18.40 \pm 9.80 *$ & $35.45 \pm 1.06^{*}$ & $<0.5$ & $346.74 \pm 95.16$ & $6.14 \pm 0.11 *$ \\
\hline \multicolumn{8}{|c|}{ Gleason score (points) } \\
\hline 6 & $175.8 \pm 8.4$ & $<4$ & $3.4 \pm 1.17$ & $44.12 \pm 0.11$ & $>0.5$ & $243.75 \pm 22.54$ & $5.37 \pm 0.08$ \\
\hline 7 & $168.8 \pm 7.1$ & $<4$ & $4.01 \pm 1.52$ & $40.01 \pm 0.18$ & $>0.5$ & $265.54 \pm 12.47$ & $5.29 \pm 0.14$ \\
\hline 8 & $160.1 \pm 5.2$ & $>4$ & $10.4 \pm 3.15$ & $38.71 \pm 1.64$ & $>0.5$ & $277.75 \pm 49.62$ & $6.40 \pm 0.04$ \\
\hline 9 & $148.8 \pm 5.4^{* *}$ & $>4$ & $18.4 \pm 2.43 * *$ & $32.41 \pm 0.24 * *$ & $<0.5$ & $290.05 \pm 80.37$ & $6.55 \pm 0.12^{* *}$ \\
\hline
\end{tabular}


A similar pattern of the changes was found in patients with metastatic lesions in regional lymph nodes (category N) compared with those patients in whom these pathological signs were not determined. It was shown that upon the cancer progression in the blood serum of patients with PC there was observed 1.3 times decrease of the LF and albumin contents (1.16 times) and the simultaneous increase of CRP and $\mathrm{Ca} /$ $\mathrm{Mg}$ (2.84 and 1.1 times, respectively), and CRP/ albumin ratios lower $(<0.5)$. Along with this, in the blood serum of patients with metastases in regional lymph nodes, there was a tendency to increased LDH. It should be noted that more significant changes in these indices were associated with a high level of PSA (Table 1).

An analysis of the results of the morphological study of primary tumors of patients with PC with metastases in regional lymph nodes showed that in these patients, unlike individuals without advanced metastases, there are present the lesions of glandular structures with significant anaplasia. In particular, in some of these glands there was a significant proliferation of atypical tumor cells with substantially altered architectonics and orientation, there was a violation of the basement membrane and invasion of tumor cells in the adjacent connec-

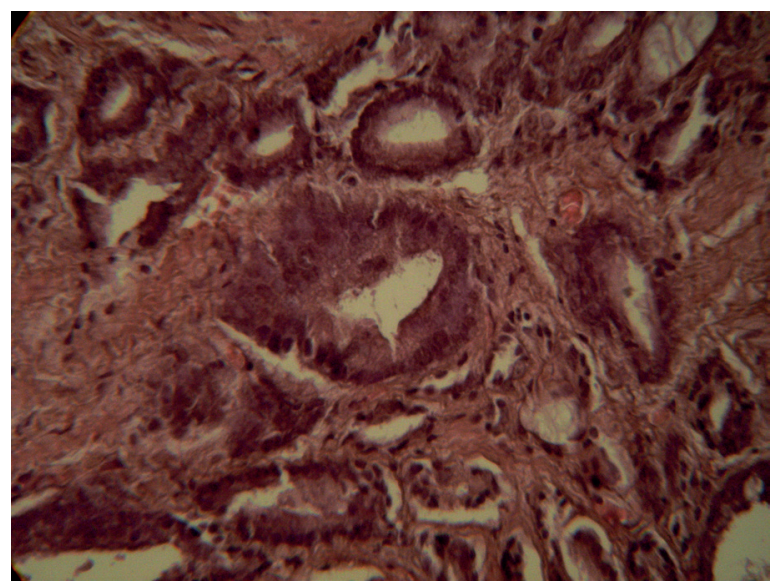

Fig. 1. Small acinar adenocarcinoma with pronounced signs of anaplasia. The impairment of the basement membrane and the invasion of the atypically proliferating tumor cells into adjacent connective tissue. $\mathrm{H} \& \mathrm{E}, \times 400$ ting tissue (Fig. 1). Somewhere, solid and trabecular structures were found. Occasionally, actively proliferating cells actually lost the phenotype of the original epithelial cells. In some cases, near these glandular structures extensive lymphocytic infiltrates were identified (Fig. 2).

It was in the blood serum of these patients that the highest values of CRP content were observed against the backdrop of significantly reduced LF and albumin content.

In the available literature $[10,13,15]$, there are only a few reports on the study of the content of CRP, albumin, $\mathrm{LDH}$, also $\mathrm{Ca} / \mathrm{Mg}$ and CRP/ albumin ratios in relation to the phenotypic and morphological features of PC. That is why, we focused on the nature of changes in BS of patients with PC, the content of LF and a number of other biochemical parameters, depending on the indices of the Gleason score, associated with the degree of PC malignancy. It was found that the values of LF, CRP, albumin, $\mathrm{Ca} / \mathrm{Mg}$ and $\mathrm{CRP} /$ albumin ratios in $\mathrm{BS}$ of patients with PC with a high degree of malignancy by the Gleason score ( $\geq 8$ points) significantly differed from those in patients with a level $\leq 7$ points. It was shown that in patients with high Gleason points, against a background of low serum LF

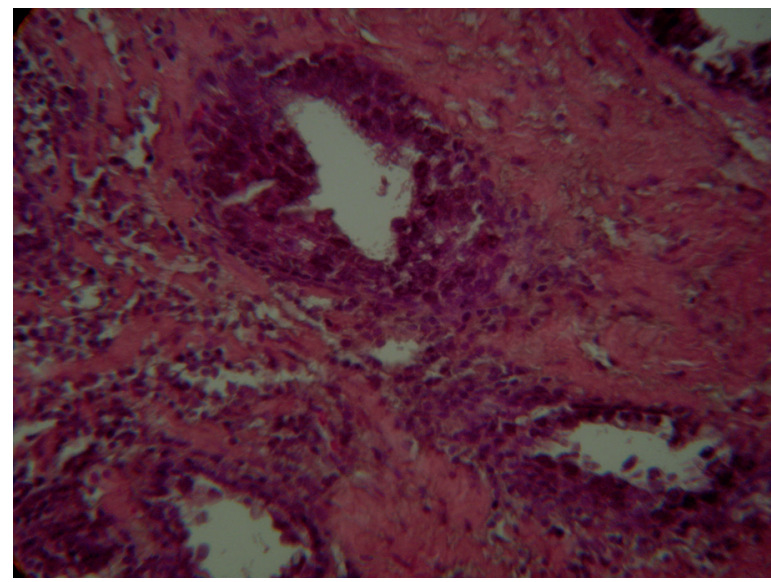

Fig. 2. Small acinar adenocarcinoma with proliferation and disorganization of growth of atypical tumor cells. Significant lymphocytic infiltration is observed in the connective tissue. $\mathrm{H} \& \mathrm{E}, \times 400$ 
and albumin, a significant increase in the $\mathrm{Ca} /$ $\mathrm{Mg}, \mathrm{CRP} /$ albumin ratios and $\mathrm{LDH}$ content was observed. The obtained data testify that in patients with a high degree of PC malignancy ( 8 and 9 points by the Gleason score and a level of $\mathrm{PSA}>4 \mathrm{ng} / \mathrm{ml}$ ) there are significant violations of various parts of the metabolic pathways in the body, which is evidence of unfavorable course of the disease.

The morphology of tumors of patients with PC of a high malignancy degree by the Gleason score, as a rule, was characterized by a variety of architectonics, including cytoarchitectonics with pronounced signs of anaplasia of tumor cells in different tumor sites. Most of these tumors were dominated by atypical, large acinar glandular structures with different compaction in terms of location and form. There was observed an uneven multilayer proliferation of the prismatic or cubic epithelium with pronounced signs of atypia, both in the cells and nuclei, with the formation of multiple papules in the lumen of the gland. The basal cell layer was absent. Tumor cells in the glands were disarranged in relation to the basement membrane. The mitoses figures, including pathological ones, are quite common. In addition, in the same tumors, areas of small acinar glandular structures covered with dark cubic epithelium with varying degrees of proliferative activity were determined. Sometimes within the tumors, cancer cells with a different character of differentiation were observed (Fig. 3).

On the contrary, in the group of patients with tumors $\leq 7$ points by Gleason score and the serum PSA levels below $4 \mathrm{ng} / \mathrm{ml}$, less significant changes in the values of all serum biochemical markers, including LF, were observed. This is consistent with the results of morphological studies. Among tumors of low malignancy degree by Gleason predominated small acinar structures, which, by the features of atypia and polymorphism, had less mosaic character and more monomorphic manifestations (Fig. 4).

For a more objective determination of the informativeness of LF among other biochemical markers and its association with the clinical and morphological characteristics of patients with $\mathrm{PC}$, correlations between these indices were

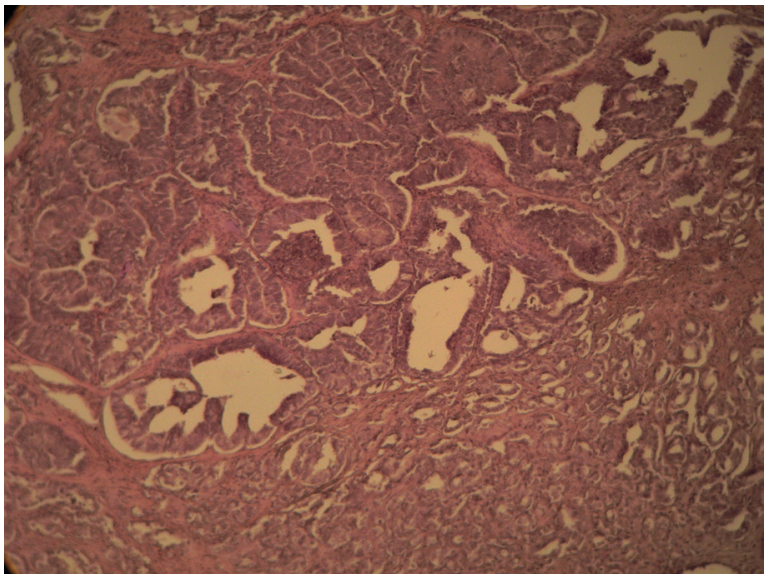

a

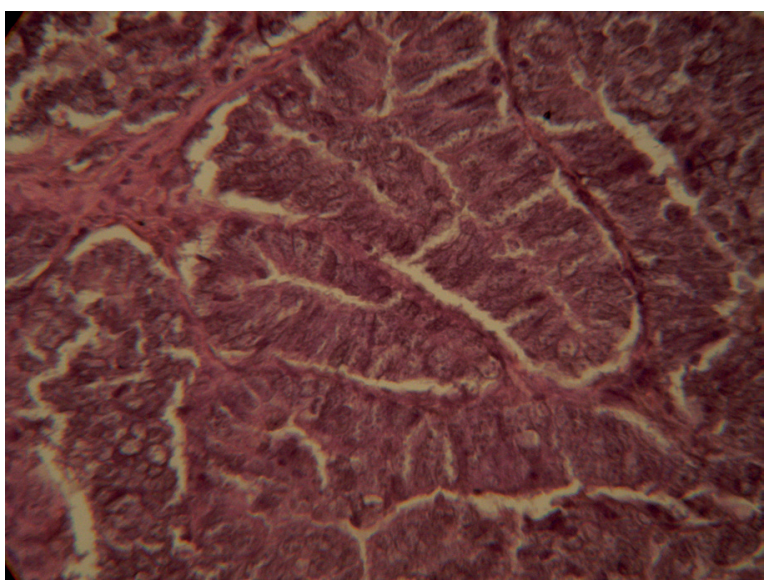

b

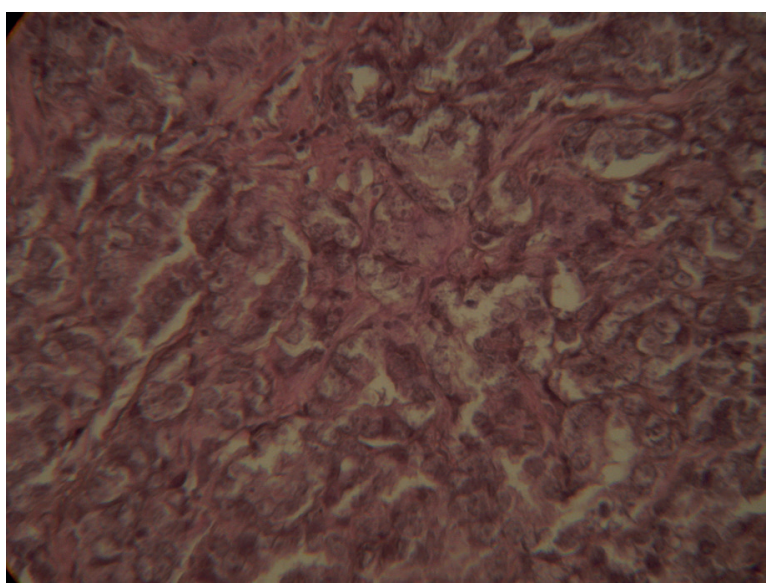

C

Fig. 3. Adenocarcinoma of high malignancy degree ( 9 points by Gleason): $\mathrm{a}$ - the predominance of large acinar structures in combination with small acinar ones, $\mathrm{H} \& \mathrm{E}, \times 200$; $b$ - tumor area with endometrioid differentiation, $\mathrm{H} \& \mathrm{E}, \times 400 ; \mathrm{c}-$ the region of low-differentiated adenocarcinoma, $\mathrm{H} \& \mathrm{E}, \times 400$ 


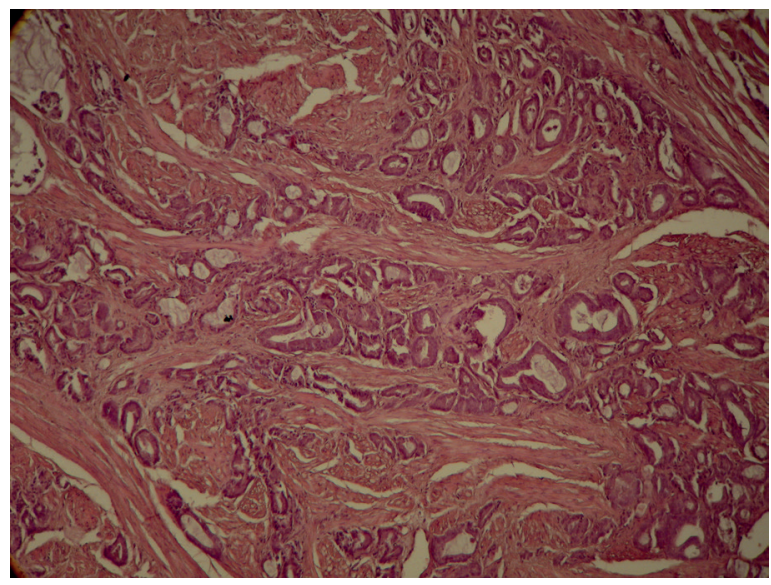

Fig. 4. Combination of large and small acinar adenocarcinomas with the predominance of the latter. The malignancy degree by the Gleason score 6 points. Monomorphic manifestations of anaplasia in the glandular structures. H\&E, $\times 200$ analyzed (Table 2).

It was found that none of the studied serum markers (LF, CRP, albumin, LDH, and CRP/ albumin and $\mathrm{Ca} / \mathrm{Mg}$ ) in patients with $\mathrm{PC}$ was changed significantly with age, except a slight increase in PSA on a background of a gradual decrease in the $\mathrm{Ca} / \mathrm{Mg}$ ratio and $\mathrm{LF}$ content. This agrees with the data of other authors regarding the slight fluctuations of these indicators in cancer patients of different age groups $[8,17$, $18]$.

In contrast, another type of correlation between the content of the above-mentioned serum markers of patients with $\mathrm{PC}$ and the stage of the process is established. In particular, the most significant inverse correlation was found between the stage of the process and the LF content, and the direct correlation - regarding

Table 2. Correlation between the content of LF, CRP, LDH, albumin, CRP/albumin and Ca/Mg ratios and the main clinical-morphological characteristics of the $\mathrm{PC}$ patients

\begin{tabular}{|c|c|c|c|c|}
\hline Index & Pairs of correlations & $\begin{array}{c}\text { Pearson correlation } \\
\text { coefficient, } \mathrm{r}\end{array}$ & $\mathrm{P}$ & Correlation \\
\hline Age & $\mathrm{LF}$ & 0.023 & $>0.05$ & None \\
& $\mathrm{CRP}$ & 0.10 & $<0.05$ & None \\
& $\mathrm{LDH}$ & 0.15 & $<0.05$ & None \\
& $\mathrm{Ca} / \mathrm{Mg}$ & -0.18 & $<0.05$ & None \\
Stage, & $\mathrm{CRP} /$ albumin & -0.12 & $>0.05$ & None \\
category T & $\mathrm{LF}$ & -0.51 & $<0.05$ & Negative \\
& $\mathrm{CRP}$ & 0.32 & $<0.05$ & Positive \\
Stage, & $\mathrm{LDH}$ & 0.12 & $>0.05$ & None \\
category N & $\mathrm{Ca} / \mathrm{Mg}$ & 0.35 & $<0.05$ & Positive \\
& $\mathrm{LF}$ & -0.42 & $<0.05$ & Negative \\
& $\mathrm{CRP}$ & 0.45 & $<0.05$ & Positive \\
& $\mathrm{LDH}$ & 0.27 & $<0.05$ & Positive \\
& $\mathrm{Ca} / \mathrm{Mg}$ & 0.40 & $<0.05$ & Positive \\
& $\mathrm{CRP} / \mathrm{albumin}$ & -0.14 & $>0.05$ & None \\
& $\mathrm{Albumin}$ & -0.21 & $>0.05$ & Negative \\
Gleason score & $\mathrm{LF}$ & -0.35 & $<0.05$ & Negative \\
& $\mathrm{CRP}$ & 0.39 & $<0.05$ & Positive \\
& $\mathrm{CRP} / \mathrm{albumin}$ & 0.24 & $>0.05$ & Negative \\
& $\mathrm{LDH}$ & 0.18 & $<0.05$ & None \\
& $\mathrm{Ca} / \mathrm{Mg}$ & 0.52 & $<0.05$ & Positive \\
& $\mathrm{Albumin}$ & -0.23 & $<0.05$ & Negative \\
\hline
\end{tabular}


the content of the CRP and the $\mathrm{Ca} / \mathrm{Mg}$ ratio. It should be noted that there is found no significant correlation between the stage of the disease and the albumin and LDH content (see Table 2).

A similar type of correlation was established between the studied biochemical parameters of PC and such an important clinical criterion of tumor progression as the presence or absence of metastatic lesions in regional lymph nodes. It has been shown that in patients with metastases in lymph nodes there is a negative correlation between this index and the LF content, and a positive correlation - with the content of CRP and the $\mathrm{Ca} / \mathrm{Mg}$ ratio. In addition, a weak link was found between regional metastasis and LDH and albumin content. The absence of a relation between lymph node metastasis lesions and the CRP/albumin ratio was noted (see Table 2).

We believe that we received interesting data on the multi directional nature of correlations between the degree of PC malignancy by the Gleason score and the content of LF, CRP, albumin, $\mathrm{LDH}, \mathrm{Ca} / \mathrm{Mg}$ and $\mathrm{CRP} /$ albumin ratios, namely, negative correlation with LF and albumin, and positive - with other investigated serum indices. It should be noted that our previous studies on the content of LF in BS of patients with breast cancer have revealed the opposing changes in LF content in relation to clinical and pathological characteristics [15]. In particular, it was found that high LF, CRP and lactate contents were observed in patients with breast cancer with basal subtype of tumors characterized by aggressive course of the disease. The obtained data at the tumor level are consistent with disorders of metabolic processes in the body. At the same time, in patients with PC of a high degree of malignancy by the Gleason score, the serum LF content was significantly lower than in patients with PC of lower malignancy. Consequently, when comparing the data obtained, we have established peculiar metabolic "scissors" regarding the content of serum LF in patients with the most common hormone-dependent malignant neoplasms - PC and breast cancer. In addition, we have proved that LF is a more informative serum marker than other biochemical markers.

Along with the mentioned aspects of the research, we considered it expedient to analyze the degree of correlation between the content of $\mathrm{LF}$, CRP, albumin, $\mathrm{LDH}$, ratios CRP/albumin, $\mathrm{Ca} / \mathrm{Mg}$ and level of PSA, in order to find out the participation of each of the above biochemical parameters in the general mechanisms of the PC pathogenesis.

The results of our studies have shown that the aggressiveness of $\mathrm{PC}$ is accompanied not only by the increase in the PSA content in BS but also by significant changes in the functioning of various parts of metabolic processes in the body. It was shown that the most significant direct correlation was determined between PSA and $\mathrm{Ca} / \mathrm{Mg}$ $(\mathrm{r}=0.46)$, less pronounced - between CRP level $(\mathrm{r}=0.34)$ and $\mathrm{CRP} /$ albumin ratio $(0.32)$. The data obtained do not contradict the literature data on possible disturbances in the redistribution of calcium and magnesium in the body of patients with PC of a high degree of malignancy [19]. It is also confirmed that the increase in the $\mathrm{Ca} / \mathrm{Mg}$ ratio in $\mathrm{BS}$ of these patients is associated with a change in the transport, homeostatic and protective functions of albumin. There is evidence that functional impairment of albumin leads to the accumulation of active testosterone in the body of PC patients, which in turn initiates the further development of the neoplastic process. Recent clinical studies have shown that an increase in the CRP concentration and the ratio of CRP to albumin in BS evidence on acute or chronic inflammation, as well as a significant violation of the transport function of albumin, which is associated with low survival rates in patients $[10,20]$. Therefore, according to some authors, in this category of patients, it is necessary to determine the level of PSA along with the content of CRP and the ratio of CRP/albumin, since it is possible to timely detect nosological forms of PC with high metastatic potential [10].

Among the studied biochemical parameters, LDH activity was less significant in comparison with PSA, which is evidence of a slight change in energy metabolism in patients with PC. However, 
in patients with a high degree of malignancy of tumors (by the Gleason score and regional lymph nodes metastasis), the activity of this enzyme was increased, indicating increased anaerobic glycolysis in the body of patients. However, among biochemical markers, only albumin and LF showed a negative correlation with PSA $(r=-0.18)$, with higher values of the coefficient for LF $(r=-0.48)$. Probably, LF and PSA are involved in various mechanisms of pathophysiological processes in PC. In our opinion, such an association between LF and PSA can indicate a high sensitivity of this protein to a complex of metabolic alterations in the body of a cancer patient regarding hormonalreceptor balance, immune response, violation of the exchange of endogenous iron. Thus, in relation to PSA, the most significant indices were the following biochemical parameters: LF content, $\mathrm{Ca} / \mathrm{Mg}$ and $\mathrm{CRP} /$ albumin ratio, and level of CRP.

At the end of the study, we conducted a correlation analysis to determine which of the above biochemical markers is closest to the LF by the magnitude of the correlation.

We have shown that the most pronounced negative correlation was observed between the content of $\mathrm{LF}$ and the $\mathrm{Ca} / \mathrm{Mg}$ ratio $(\mathrm{r}=-0.46)$, less significant - with the ratio of CRP/albumin and level of LDH. The maximum values of the correlation coefficients (direct dependence) were found between the content of LF and CRP $(\mathrm{r}=0.36)$.

In conclusion, the study showed that the analyzed biochemical markers (LF, CRP, albumin, $\mathrm{LDH}$, also $\mathrm{CRP} /$ albumin and $\mathrm{Ca} / \mathrm{Mg}$ ratios) are involved in various links of metabolic pathways in the body and have different degrees of manifestation and significance in PC patients with progression tumor process. Among all the analyzed serum biochemical markers, more informative indices $(\mathrm{Ca} / \mathrm{Mg}$ and $\mathrm{CRP} /$ albumin ratio, LF level) and those that did not have significance in the course of the tumor process $(\mathrm{LDH})$, were determined. The obtained data convincingly indicate that serum LF can be used as an extratumoral marker, which provides new additional information on the characteristics of the clinical course of PC.

The work was carried out with the support of the Research Program of the National Academy of Sciences of Ukraine "Molecular Genetic and Biochemical Mechanisms for the Regulation of Cellular and Systemic Interactions under Physiological and Pathological Conditions" (2017-2021) within the framework of the research work "Molecular and biological factors of heterogeneity of malignant cells and the variability of clinical course of hormone dependent tumors "(2.2.5.411, 0117U002034) and the departmental theme "The role of lactoferrin in the initiation and progression of the most common hormone-dependent malignant tumors" (2.2.5.401, 2016-2018, 0115U005381).

The authors of this study confirm that the research and publication of the results were not associated with any conflicts regarding commercial or financial relations, relations with organizations and/or individuals who may have been related to the study, and interrelations of coauthors of the article.

\section{Ю.В. Лозовская, Л.А. Налескина, Т.В. Задворный, И.Н. Андрусишина, И.В. Жулькевич, Э.А. Стаховский, Л.Н.Кунская, Н.Ю. Лукьянова \\ ВЗАИМОСВЯЗЬ АГРЕССИВНОСТИ РАКА ПРЕДСТАТЕЛЬНОЙ ЖЕЛЕЗЫ И ОПУХОЛЕАССОЦИИРОВАННЫХ МАРКЕРОВ В СЫВОРОТКЕ КРОВИ}

У больных раком предстательной железы изучена зависимость содержания сывороточных опухолеассоциированных маркеров: лактоферрин (ЛФ), С-реактивный протеин (СРП), альбумин, лактатдегидрогеназа (ЛДГ) и соотношений $\mathrm{Ca} / \mathrm{Mg}$ и СРП/альбумин от клинико-патологических характеристик заболевания. А также изучена степень злокачественности новообразований по Глисону и наличие метастазов в регионарные лимфатические узлы. Показано, что в сыворотке крови больных III стадии по сравнению c II происходило снижение в 1,4 раза содержания ЛФ и соотношения СРП/альбумин на фоне достоверного увеличения содержания СРП и соотношения $\mathrm{Ca} / \mathrm{Mg}$ (в 2,75 и 1,12 раза соответственно). Наряду с этим у больных с метастатическим поражением регионарных лимфатических узлов по сравнению с пациентами без этих признаков 
выявлено снижение в 1,3 раза содержания ЛФ и альбумина в 1,16 раза при одновременном росте содержания СРП и соотношения $\mathrm{Ca} / \mathrm{Mg}$ (в 2,84 и 1,1 раза соответственно) на фоне снижения СРП/альбумин. Показано, что в сыворотке крови больных с высокой степенью злокачественности новообразований (8 и 9 баллов по шкале Глисона) и содержанием простатспецифического антигена более 4 нг/мл, по сравнению с пациентами с менее выраженными признаками опухолевой прогрессии, наблюдалось существенное снижение содержания сывороточного ЛФ и альбумина на фоне повышенного соотношений $\mathrm{Ca} / \mathrm{Mg}, \mathrm{CPП/альбумин}$ и содержания ЛДГ. Указанные различия в разных звеньях метаболических путей в организме больных раком предстательной железы с более агрессивным проявлением заболевания свидетельствуют о неблагоприятном течении опухолевого процесса. Полученные результаты дают основания полагать, что сывороточный ЛФ может быть использован как дополнительный внеопухолевый маркер для прогноза рака предстательной железы.

Ключевые слова: рак предстательной железы; ассоциированные с опухолью биохимические маркеры; простатспецифический антиген; шкала Глисона.

\section{Ю. В. Лозовська ${ }^{1}$, Л.А. Налсскіна ${ }^{1}$, Т.В. Задворний ${ }^{1}$, I.М. Андрусішина ${ }^{2}$, І.В. Жулькевич ${ }^{3}$, Е.О. Стаховський ${ }^{4}$, Л.М. Кунська ${ }^{1}$, Н.Ю. Лук'янова ${ }^{1}$ \\ ВЗАСМОЗВ'ЯЗОК АГРЕСИВНОСТІ РАКУ ПЕРЕДМІХУРОВОЇ ЗАЛОЗИ І ПУХЛИНО- АСОЦІЙОВАНИХ МАРКЕРІВ У СИРОВАТ- ЦІ КРОВІ}

Досліджено вміст сироваткових пухлиноасоційованих маркерів: лактоферин (ЛФ), С-реактивний протеїн (СРП), альбумін, лактатдегідрогеназа (ЛДГ), співвідношення $\mathrm{Ca} / \mathrm{Mg}$ та СРП/альбумін, у хворих на рак передміхурової залози залежно від клініко-патологічних характеристик захворювання. Крім того, визначено ступінь злоякісності новоутворень за Глісоном і наявність метастазів у регіонарні лімфатичні вузли. Показано, що у сироватці крові хворих на рак III стадії порівняно із II знижувався у 1,4 раза вміст ЛФ та зменшувалося співвідношення СРП/ альбумін на фоні достовірного збільшення вмісту СРП та співвідношення $\mathrm{Ca} / \mathrm{Mg}$ (у 2,75 та 1,12 раза відповідно). Водночас у хворих із метастатичним ураженням регіонарних лімфатичних вузлів порівняно із пацієнтами без цих ознак виявлено зменшення у 1,3 раза вмісту ЛФ та альбуміну у 1,16 раза при одночасному зростанні вмісту СРП та співвідношення $\mathrm{Ca} / \mathrm{Mg}$ (у 2,84 та 1,1 раза відповідно) та зниження СРП/альбумін. Показано, що у сироватці крові хворих із високим ступенем злоякісності новоутворень (8 та 9 балів за шкалою Глісона) та вмістом простатспецифічного антигена (ПСА) більш ніж 4 нг/мл, порівняно зі значеннями у пацієнтів з менш вираженими ознаками пухлинної прогресії, суттєво знижувався вміст сироваткового ЛФ та альбуміну на фоні підвищеного співвідношення $\mathrm{Ca} / \mathrm{Mg}$, СРП/альбумін і вмісту ЛДГ. Зазначені відмінності у різних ланках метаболічних шляхів в організмі хворих на рак передміхурової залози з більш агресивним проявом захворювання свідчать про несприятливий перебіг пухлинного процесу. Отримані результати дають підстави вважати, що сироватковий ЛФ може бути використаний як додатковий позапухлинний маркер для прогнозу цього захворювання.

Ключові слова: рак передміхурової залози; пухлиноасоційовані біохімічні маркери; простатспецифічний антиген; шкала Глісона.

${ }^{1}$ Інститут експериментальної патології, онкології і радіобіології ім. Р.Є. Кавецького НАН України, Київ;

${ }^{2}$ ДУ «Інститут медицини праці імені Ю.І. Кундієва НАМН», Київ;

${ }^{3}$ Тернопільський національний медичний університет імені І.Я. Горбачевського;

${ }^{4}$ Національний інститут раку, Київ;

e-mail:Lozovskaya.2012@ukr.net

\section{REFERENCES}

1. Tao ZQ, Shi AM, Wang KX, Zhang WD. Epidemiology of prostate cancer: current status. Eur Rev Med Pharmacol Sci. 2015;9(5):805-12.

2. Mohler JL, Armstrong AJ, Bahnson RR, et al. Prostate cancer. J Natl Compr Canc Netw. 2016 Jan;14(1):19-30.

3. Hsing AW, Chokkalingam AP. Prostate cancer epidemiology. Front Biosci. 2006 May 1;11:1388-413.

4. Esfahani M, Ataei N, Panjehpour M. Biomarkers for evaluation of prostate cancer prognosis. Asian Pac J Cancer Prev. 2015;16(7):2601-11.

5. Thorstenson A, Garmo H, Adolfsson J, Bratt O. Cancer specific mortality in men diagnosed with prostate cancer before age 50 years: a nationwide population based study. J Urol. 2017 Jan;197(1):61-6.

6. Jemal A, Fedewa SA, Ma J, Siegel R, Lin CC, Brawley O, Ward EM. Prostate cancer incidence and PSA testing patterns in relation to USPSTF screening recommendations. JAMA. 2015 Nov 17;314(19):2054-61.

7. Epstein JI, Zelefsky MJ, Sjoberg DD, et al. A contemporary prostate cancer grading system: a validated alternative to the Gleason score. Eur Urol. 2016;69:428-35.

8. Hashimoto N. Evaluation of the relationship between C-reactive protein and prostate cancer. Clin Oncol. 2016;1:1005-11.

9. Gómez-Gómez E, Carrasco-Valiente J, Campos-Hernández $\mathrm{J}$, et al. Clinical association of metabolic syndrome, Creactive protein and testosterone levels with clinically significant prostate cancer. J Cell Mol Med. 2019 Feb;23(2):934-942.

10. Li N, Tian GW, Wang Y, Zhang H, Wang ZH, Li G. Prognostic role of the pretreatment C-reactive protein/ albumin ratio in solid cancers: a meta-analysis. Sci Rep. 2017 Jan 27;7:41298. 
11. Yamashita S, Kohjimoto Y, Iguchi T, et al. A. Prognostic factors and risk stratification in patients with castrationresistant prostate cancer receiving docetaxel-based chemotherapy. BMC Urol. 2016 Mar 22;16:13.

12. Wulaningsih W, Holmberg L, Garmo H, et al. Serum lactate dehydrogenase and survival following cancer diagnosis. Br J Cancer. 2015 Nov 3;113(9):1389-96.

13. Asare GA, Ngala RA, Afriyie D, et al. Calcium - Magnesium imbalance implicatedin benign prostatic hyperplasia and restoration by a phytotherapeutic drug - Croton membranaceus Müll. Arg. BMC Complement Altern Med. 2017; Mar 11;17(1):152.

14. Fernández-Menéndez S, Fernández-Sánchez ML, González-Iglesias $\mathrm{H}$, et al. Iron bioavailability from supplemented formula milk: effect of lactoferrin addition. Eur J Nutr. 2017;56:2611-20.

15. Lozovskaya YuV, Lukyanova NYu, Zadvorniy TV, Sobchenko SA, Chekhun VF. Prognostic serum biomarkers of breast cancer: lactoferrin, lactate dehydrogenase and C-reactive protein. Oncol J. 2016;10:33-41. [Belarusian].

16. Kizalaite A, Brimiene V, Brimas G, Kiuberis J, Tautkus S, Zarkov A, Kareiva A. Determination of trace elements in adipose tissue of obese people by microwave-assisted digestion and inductively coupled plasma optical emission spectrometry. Biol Trace Elem Res. 2019 May;189(1):10-17.

17. Kim SW, Lee YJ, Chung LW. A Higher ratio of serum calcium to magnesium is associated with aggressive clinicopathological characteristics in the patients who underwent radical prostatectomy. Korean J Urol Oncol. 2018;16:25-31.

18. Sun Y, Selvaraj S, Varma A, et al. Increase in serum $\mathrm{Ca}^{2+}$ $\mathrm{Mg}^{2+}$ ratio promotes proliferation of prostate cancer cells by activating TRPM7 channels. J Biol Chem. 2013 Jan 4;288(1):255-63.

19. Baruah SJ, Rajeev TP, Bora SJ. Correlation of serum calcium \& magnesium ratio with s. PSA, prostate gland weight $\&$ Gleason score in carcinoma prostate - a prospective, age matched control study. JASA. 2015;22:6-12.

20. Arthur R, Williams R, Garmo H, Holmberg L, Stattin P, Malmström H, Lambe M, Hammar N, Walldius G, Robinsson D, Jungner I, Van Hemelrijck M. Serum inflammatory markers in relation to prostate cancer severity and death in the Swedish AMORIS study. Int J Cancer. 2018 Jun 1;142(11):2254-62. 